\title{
Measurement of U.S. Equity Mutual Funds' Environmental Responsibility Attractiveness for an Individual Investor
}

\author{
Paz Méndez¹, Bouchra M'Zali², Pascal Lang³, Blanca Pérez-Gladish1 ${ }^{*}$ \\ ${ }^{1}$ Department of Quantitative Economics, Faculty of Economics and Business, University of Oviedo, Oviedo, \\ Spain \\ ${ }^{2}$ UQAM, ESG-CRSDD, Montréal, Canada \\ ${ }^{3}$ Laval University, Québec, Canada \\ Email: mpmendez@uniovi.es, mzali.bouchra@uqam.ca, pascal.lang@fsa.ulaval.ca, ”bperez@uniovi.es
}

Received 16 January 2014; revised 18 February 2014; accepted 23 March 2014

Copyright $(02014$ by authors and Scientific Research Publishing Inc.

This work is licensed under the Creative Commons Attribution International License (CC BY).

http://creativecommons.org/licenses/by/4.0/

(c) () Open Access

\begin{abstract}
Socially responsible mutual funds, also known as socially responsible invested funds, are one of the main instruments of Socially Responsible Investment (SRI). The term "fund" is used to refer to a ready-made financial product where investor's money is pooled into a portfolio and a fund/investment manager decides which shares to buy. Therefore, this financial product is attractive for passive investors without a high degree of financial knowledge. Nevertheless, investment tools aimed at assisting the investors in their selection of socially responsible companies which serve best their social and environmental values are rather scare and this lack of tools assisting investors in SRI is even more important when we refer to socially responsible mutual funds. The aim of this paper is to assist individual passive investors in their investment decisions providing them with a ranking of mutual funds adjusted to their social, environmental and ethical particular preferences. The proposed approach is illustrated with a real US equity mutual funds' ranking example.
\end{abstract}

\section{Keywords}

Socially Responsible Investment; Environment; Equity Mutual Funds Evaluation; Multicriteria Decision Analysis; Decision Support Systems

\section{Introduction}

Investors seeking to invest in Social and Environmental Responsible (SER) firms have grown to become an un-

\footnotetext{
*Corresponding author.
}

How to cite this paper: Méndez, P., M'Zali, B., Lang, P. And Pérez-Gladish, B. (2014) Measurement of U.S. Equity Mutual Funds' Environmental Responsibility Attractiveness for an Individual Investor. Open Journal of Business and Management, 2, 85-101. http://dx.doi.org/10.4236/ojbm.2014.22012 
avoidable fact in capital markets. Indeed, the last financial crisis and the succession of financial scandals have catalyzed and reinforced the SER investors' movement. In order to assist these investors to identify and select socially and environmentally responsible companies, several social rating agencies try to standardize social and environmental information conveyed in connection with the companies and main stakeholders. Thus, in the United States, KLD offers an aggregate rating of corporate social responsibility for more than 3000 US companies. This rating is based on 8 social and environmental dimensions, which are in turn, integrated by more than 60 criteria.

With regards to the rating of socially responsible mutual funds, few tools are available for investors. The SRI strategy most used by socially responsible mutual funds is screening which is the practice of evaluating mutual funds based on social, environmental, ethical and/or good corporate governance criteria. Positive screening implies investing in profitable companies that make positive contributions to society. Conversely, negative screening implies avoiding investing in companies whose products and business practices are harmful to individuals, communities, or the environment. Most of the papers which can be found in the literature trying to measure mutual funds' social responsibility degree rely on the number of screens applied by the fund. References [1]-[5] proposed screening intensity (number of applied screens) as a proxy of mutual funds' social degree. References [2] [5] took also into account the type of applied screen: positive and/or negative and if the fund checks for direct and indirect infringement of social issues. Reference [6] proposed an AHP-based ranking method for socially responsible mutual funds which takes into account together with the screening intensity the engagement policy of the fund, the followed SRI research process, control of companies, external control of the fund, competence of fund managers and communication with companies and investors, among others. Reference [6] called these criteria "Quality of Information" as referred to the transparency and credibility of the non-financial information provided by the fund manager about SRI funds.

The evaluation model proposed in this paper, instead of using screening intensity for measuring the social responsibility degree of the mutual funds, evaluates the Corporate Social Performance of each of the firms invested in by the equity mutual funds, using KLD database for U.S. companies. Then, given the percentage invested in by the mutual fund in each company, the scores are aggregated into one quantitative measure for each mutual fund. In addition, a new criterion, quality of SRI management, is included in the model to incorporate information about the companies' selection process, investment policy, screening process, research process and the level of expertise of the fund managers with respect to SRI.

SER investors are motivated by different values and will seek companies respecting particular dimensions of Corporate Social Responsibility (CSR). Therefore, in this paper, the proposed evaluation model depends on the investor's personal preferences reflecting the importance given by the investor to each decision making criterion. The weights given to the different criteria can change from one investor to another as they depend on diverse facts as the country, culture, religion or personal values and beliefs of the investor. In this paper, an approach is presented that allows measurement of the socially responsible attractiveness of mutual funds for a particular investor in terms of a set of socially responsible criteria.

With this aim, a mutual funds' evaluation model is designed based on MACBETH. Measuring Attractiveness by a Categorical Based Evaluation Technique asks only for qualitative pairwise comparison judgments of the difference in value between alternatives (see [7]-[9] for references and mathematical foundations and [10] [11] for some applications). MACBETH is visually supported by the M-MACBETH software [8]. According to MACBETH procedure, the following steps are followed:

Step 1. Identification of the relevant investment criteria.

Step 2. Definition of descriptors of quantitative performance for each criterion.

Step 3. Definition of "targets" associated with each criterion: "good" and "neutral" performance levels.

Step 4. Obtaining of value functions for each criterion in order to transform qualitative performance levels into quantitative values.

Step 5. Criteria weighting.

Step 6. Aggregation additive procedure.

The structure of the paper is the following: in next section, descriptors of performance for each criterion are presented and reference levels and value functions for each criterion are obtained from dialogue with the individual investor. Next section presents criteria weighting and aggregation of criteria using an additive model. Finally, conclusions are presented.

Some components, such as multi-leveled equations, graphics, and tables are not prescribed, although the var- 
ious table text styles are provided. The formatter will need to create these components, incorporating the applicable criteria that follow.

\section{Identification of Investment Criteria}

In this work we have concentrated on the U.S. case although the proposed ranking could be adapted to other countries in order to assist investors with different beliefs or personal values. Three main areas of concern or dimensions have been considered. One, "Quality of the SRI Management" related to the managers' investment practices, their experience and the transparency and credibility of the information provided (Dimension 1); another one, "Social, Environment and Governance, SEG", corresponding to socially responsible practices of companies invested in by the mutual funds (Dimension 2); and, finally, "Financial Performance" (Dimension 3). For each of these areas of concern several criteria have been defined to a total of 10 (see Figure 1).

Mutual funds managers can influence the degree of social and environmental responsibility of their funds as they define investment strategies, the research processes and selection rules [12]. Therefore, it seems adequate to incorporate in the evaluation model criteria about the quality of the SRI management. Thus, we have considered 5 criteria belonging to this dimension: screening approach, advocacy and public policy, research process, external control and manager's SRI competence (see Table 1):

Social, Environmental and Governance (SEG) criteria were derived taking into account KLD's methodology for their Corporate Social Ratings Monitor (KLD, 2007) [13]. In this work we will only focus on the Environmental dimension and we will evaluate environmental responsibility of equity mutual funds from the evaluation of the firms invested in by the mutual fund taking into account KLD criteria: climate change, products and services, operations management and other.

KLD uses screens to monitor corporate social performance of U.S. firms. They have positive and negative screens. The positive screens indicate strengths of a firm and the negative screens indicate weaknesses. The former suggest that the firm is engaged in some socially responsible actions which may have positive effects on society, and the latter implies that it may have negative effects on society. Finally, the financial dimension includes one criterion, adjusted risk (see Figure 1).

\section{Descriptors of Performance and Value Functions for Each Criterion}

A total of 46 real U.S. domiciled large cap equity mutual funds constitute our set of alternatives or investment options. Our universe is composed by seasonal funds (age equal or greater than 10 years). These funds have at least 70\% of assets in domestic stocks. They are characterized by Morningstar Ltd based on style and size of the stocks they own. In this paper we have considered large market capitalization funds belonging to growth or blend categories. Growth funds main goal is capital appreciation with little or no dividend payouts. Blend funds are funds with portfolios made up of a combination of value and growth stocks. Value funds are stock mutual

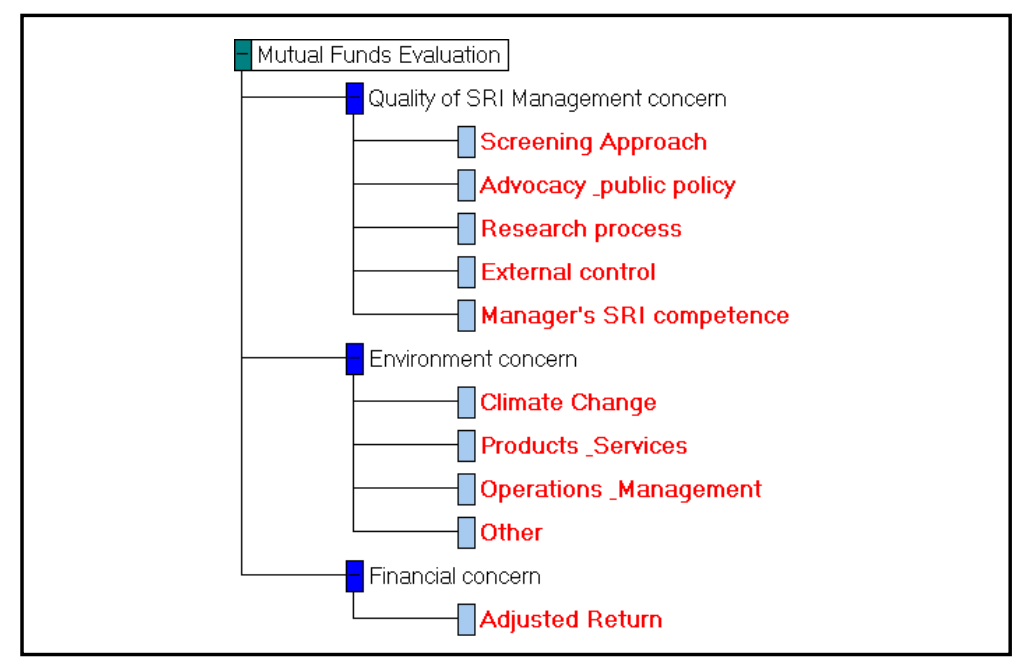

Figure 1. M-MACBETH’s value tree. 
Table 1. Quality of social responsibility management.

\begin{tabular}{cc} 
Criteria & Description \\
\hline
\end{tabular}

Screening Approach Type of screen: Positive and/or negative.

Description of the aims of the engagement policy. How does the fund prioritize which companies it will engage with? Engagement employed methods. How is the effectiveness of engagement activity monitored? What further steps, if any, are taken if engagement is considered unsuccessful? How, and

Advocacy \& Public Policy how frequently, are engagement activities communicated to investors and other stakeholders? Does the fund have a voting policy? If so, what is it? Does the fund disclose its voting practices and reasoning for decisions? If so, where can this information be found? Does the fund sponsor/co-sponsor shareholder resolutions?

Does the fund manager use an in-house research team and/or an external research team? Is there an external control or external verification process in place for the research process? Where an Advisory Committee is used, description of responsibilities. How frequently is the research process reviewed? What research findings are disclosed to the public? How?

Research process Some funds have their own internal research team analyzing company activities in order to indentify suitable investments. Other use external research providers such as rating agencies to get that information. In the case of an independent ethical committee it is necessary to know if it has the ultimate say on policy changes and company investments or if it delegates the responsibility to the fund manager.

External Control Engage in an ethical audit of fund periodically. Signature of transparency guidelines.

Competence of the fund manager Provision of information about the SRI education of the fund manager.

Own source based on [6].

funds that primarily hold stocks that are deemed to be undervalued in price and that are likely to pay dividends. Financial and non-financial data have been considered for 2007 in order to illustrate the presented example.

Performance of mutual funds on criteria belonging to the “Quality of SRI Management” and "Environment” areas of concern is of qualitative nature. The descriptors proposed in this work are constructed on the basis of the identification, for each criterion, of equity mutual funds' strengths and concerns which are based on KLD's strengths and concerns for U.S. companies. For the "Quality of SRI management” and based on dialogue with experts from rating agencies, only strengths have been considered (see Table 2) with the aim of rewarding “good” practices.

Based on information provided in the mutual funds websites and Social Investment Forum, we have computed, for each criterion $i$, the number of strengths accomplished by each mutual fund, $f$ :

$$
Q M_{i}^{f}=\sum_{k=1}^{K_{i}} S_{k}^{i}
$$

And, from discussion with the individual investor different levels of qualitative performance have been identified for these criteria based on the number of strengths accomplished by the fund. The investor established two reference levels for each criterion, "neutral” and "good”. Reference levels for "neutral” and "good” have been highlighted with yellow and green colors, respectively, in the following tables (Table 3).

Then, a value scale, $v\left(Q M_{i}{ }^{f}\right)$, is constructed from discussion with a real individual investor, for each criterion within this dimension (see Figure 2) following a questioning-answering process supported by the MMACBETH software [8]. The investor was asked to compare the difference in attractiveness between each two performance levels completing the upper triangular part of the judgments matrix: the investors was asked to compare a very good performance with a weak performance; then, a good performance with a weak performance and so on, until completing the last column in the matrix. Then, a very good performance was compared with the rest of performance levels, completing the first row of the matrix from right to left. Finally, second best performance level, a good performance was compared with the other performance levels completing the rest of the matrix.

Once the judgments have been obtained, and after checking consistency, M-MACBETH created a numerical scale which was discussed with the investor until she agreed with it. "Neutral" performance has been given a value score of zero and "Good” performance a value score of one. 
Table 2. Description of strengths of criteria within “Quality of SRI Management” dimension.

\begin{tabular}{|c|c|c|}
\hline Criteria $i$ & $S_{k}^{i}$ & Strengths \\
\hline \multirow{4}{*}{$\begin{array}{l}\text { Screening } \\
\text { Approach }\end{array}$} & $S_{1}^{1}$ & - The fund indicates the explicit criteria for screening decisions. \\
\hline & $S_{2}^{1}$ & - The fund applies social screening first, then financial screening. \\
\hline & $S_{3}^{1}$ & $\begin{array}{l}\text { - If the fund applies negative screening it totally excludes investments in certain activities, not } \\
\text { allowing restricted investment, which means, avoiding only poorer performers in those activities. }\end{array}$ \\
\hline & $S_{4}^{1}$ & - The fund takes into account not only direct but also indirect infringement of screens. \\
\hline \multirow{3}{*}{$\begin{array}{l}\text { Advocacy \& } \\
\text { Public Policy }\end{array}$} & $S_{1}^{2}$ & - The fund has a proxy voting policy and discloses voting practices and reasoning for decisions. \\
\hline & $S_{2}^{2}$ & - The fund sponsor/co-sponsors shareholder resolutions. \\
\hline & $S_{1}^{3}$ & - The fund presents a description of its SRI research methodology and process. \\
\hline \multirow[t]{2}{*}{ Research process } & $S_{2}^{3}$ & $\begin{array}{l}\text { - The fund has its own internal research team composed by experts in SRI analyzing company } \\
\text { activities in order to indentify suitable investments. }\end{array}$ \\
\hline & $S_{3}^{3}$ & - The fund uses external research expert providers such as rating agencies to get that information. \\
\hline External Control & $S_{1}^{4}$ & - The fund is engaged in an ethical external audit periodically. \\
\hline $\begin{array}{l}\text { Manager's SRI } \\
\text { competence }\end{array}$ & $S_{1}^{5}$ & - The fund provides information about the SRI education of the fund manager. \\
\hline
\end{tabular}

Source: Own elaboration.

Table 3. Descriptor of qualitative performance for criteria within the “Quality of SRI Management” dimension.

\begin{tabular}{cc}
\hline Levels of performance & Description \\
\hline Very good & All the strengths are accomplished \\
Good & There are some strengths but not all \\
Neutral & There is no information provided \\
Weak & There are no strengths \\
\hline
\end{tabular}

\begin{tabular}{|c|c|c|c|c||r|}
\hline & Very Good & Good & Neutral & Weak & $\begin{array}{c}\text { Current } \\
\text { scale }\end{array}$ \\
\hline Very Good & no & moderate & strong & v. strong & 3 \\
\hline Good & & no & weak & moderate & 1 \\
\hline Neutral & & & no & weak & 0 \\
\hline Weak & & & & no & -1 \\
\hline
\end{tabular}

Figure 2. M-MACBETH consistent matrix of judgments for “Quality of SRI management”.

For the "Environment" dimension we defined descriptors of qualitative performance for each of the criteria. With this aim, we first computed the qualitative environmental performance of the companies invested in by the equity mutual funds using KLD’s binary variables for strengths and concerns. Following KLD procedure the variable is equal to one if the firm meets a strength/concern environmental criterion and equal to zero otherwise.

Then, we compute each firm, $s$, performance in each criterion $\left(F_{i s}\right)$ belonging to the environment dimension in the following way (see Table 4 for de description of the strengths, $S_{k}^{i}$, and concerns $C_{u}^{i}$ for each criterion, i:

$$
F_{i s}=\sum_{k=1}^{K_{i}} S_{k}^{i}-\sum_{u=1}^{U_{i}} C_{u}^{i}
$$


Performance levels (including reference levels) for the above criteria have been obtained from discussion with the investor and are displayed in Table 5, Table 6 and Table 7.

The value scales obtained from an interactive discussion with the investor using M-MACBETH, for the different criteria within a certain dimension (where $v\left(F_{i s}\right)$ is the value of the firm $s$ with respect to criterion $i$ ), were obtained as previously described for the "Quality of SRI management" criteria (Figures 3-6).

\section{Table 4. Description of strengths and concerns for criteria within "Environment” dimension.}

\begin{tabular}{|c|c|c|}
\hline Criteria & $S_{t}^{i}, C_{u}^{i}$ & Descriptors \\
\hline \multirow{2}{*}{$\begin{array}{l}\text { Climate } \\
\text { Change }\end{array}$} & $S_{1}^{1}$ & $\begin{array}{l}\text { - The company has taken significant measures to reduce the contributions of their operations to global } \\
\text { climate change and air pollution through the use of renewable energy, other clean fuels, or through the } \\
\text { introduction of energy efficient programs or sale of products promoting energy efficiency. }\end{array}$ \\
\hline & $C_{1}^{1}$ & $\begin{array}{l}\text { - The company derives substantial revenues, directly or indirectly, from the sale of coal or oil and its } \\
\text { derivative fuel products. }\end{array}$ \\
\hline \multirow{3}{*}{$\begin{array}{l}\text { Products \& } \\
\text { Services }\end{array}$} & $S_{1}^{2}$ & $\begin{array}{l}\text { - The company derives substantial revenues from the development of innovative products with environ- } \\
\text { mental benefits, including remediation products, environmental services, or products that promote the } \\
\text { efficient use of energy or it has developed innovative products with environmental benefits. (The term } \\
\text { "environmental service” does not include services with questionable environmental effects, such as } \\
\text { landfills, incinerators, waste-to-energy plants, and deep injection wells). }\end{array}$ \\
\hline & $C_{1}^{2}$ & $\begin{array}{l}\text { - The company manufactures ozone depleting chemicals such as HCFCs, methyl chloroform, methylene } \\
\text { chloride, or bromines. }\end{array}$ \\
\hline & $C_{2}^{2}$ & - The company is a substantial producer of agricultural chemicals, including pesticides. \\
\hline \multirow{6}{*}{$\begin{array}{l}\text { Oper. } \\
\text { Manag. }\end{array}$} & $S_{1}^{3}$ & $\begin{array}{l}\text { - The company has strong pollution prevention programs, including both emissions and toxic-use } \\
\text { reduction programs. }\end{array}$ \\
\hline & $S_{2}^{3}$ & $\begin{array}{l}\text { - The company is either a substantial user of recycled materials in its manufacturing processes, or a major } \\
\text { firm in the recycling industry. }\end{array}$ \\
\hline & $S_{3}^{3}$ & $\begin{array}{l}\text { - The company has demonstrated a superior commitment to management systems through ISO } 14001 \\
\text { certification and other voluntary programs. }\end{array}$ \\
\hline & $C_{1}^{3}$ & $\begin{array}{l}\text { - The company has substantial liabilities for hazardous waste, or has recently paid significant fines or civil } \\
\text { penalties for waste management violations. }\end{array}$ \\
\hline & $C_{2}^{3}$ & $\begin{array}{l}\text { - The company has recently paid substantial fines or civil penalties for, or it has a pattern of controversies } \\
\text { regarding, violations of air, water, or other environmental regulations. }\end{array}$ \\
\hline & $C_{3}^{3}$ & $\begin{array}{l}\text { - The company's emissions of toxic chemicals into the air and water from individual plants are notably } \\
\text { high. }\end{array}$ \\
\hline \multirow{2}{*}{ Other } & $S_{1}^{4}$ & - Other Strengths. \\
\hline & $C_{1}^{4}$ & - Other Concerns. \\
\hline
\end{tabular}

Source: KLD.

Table 5. Descriptor of firms' qualitative performance for "Climate Change" and "Others" within the "Environment" dimension.

\begin{tabular}{c|c}
\hline Levels of performance & \multicolumn{1}{c}{ Description } \\
\hline Good & There are not concerns, only strengths \\
Neutral & There are not concerns or strengths \\
Weak & The number of concerns is greater than the number of strengths which is different than zero \\
Very Week & There are not strengths, only concerns \\
\hline
\end{tabular}


Table 6. Descriptor of firms' qualitative performance for "Products and Services” within the "Environment” dimension.

\begin{tabular}{|c|c|}
\hline Levels of performance & Description \\
\hline Strongly Good & There are not concerns, only strengths \\
\hline Very Good & There are equal number of strengths and concerns \\
\hline Good & The number of concerns is greater than the number of strengths which is different than zero \\
\hline Neutral & There are not concerns or strengths \\
\hline Weak & There are not strengths but some concerns \\
\hline Very Week & There are not strengths, but all possible concerns \\
\hline
\end{tabular}

Table 7. Descriptor of firms’ qualitative performance for “Operations Management” within the “Environment” dimension.

\begin{tabular}{|c|c|}
\hline Levels of performance & Description \\
\hline Strongly Good & There are not concerns, only strengths \\
\hline Very Good & The number of strengths is greater than the number of concerns which is not zero \\
\hline Good & There are equal number of strengths and concerns \\
\hline Neutral & There are not concerns or strengths \\
\hline Weak & The number of concerns is greater than the number of strengths which is not zero \\
\hline Very Week & There are not strengths, only concerns \\
\hline
\end{tabular}

\begin{tabular}{|c|c|c|c|c||r|}
\hline & Good & Neutral & Weak & Very Weak & $\begin{array}{c}\text { Current } \\
\text { scale }\end{array}$ \\
\hline Good & no & moderate & strong & positive & 1 \\
\hline Neutral & & no & moderate & positive & 0 \\
\hline Weak & & & no & positive & -1 \\
\hline Very Weak & & & & no & -2 \\
\hline
\end{tabular}

Figure 3. M-MACBETH consistent matrix of judgments for "Climate Change".

\begin{tabular}{|c|c|c|c|c|c|c|r|}
\hline & Strongly Good & Very Good & Good & Neutral & Weak & Very Weak & $\begin{array}{c}\text { Current } \\
\text { scale }\end{array}$ \\
\hline Strongly Good & no & positive & positive & positive & positive & positive & 3 \\
\hline Very Good & & no & positive & positive & positive & positive & 2 \\
\hline Good & & & no & moderate & strong & positive & 1 \\
\hline Neutral & & & & no & moderate & positive & 0 \\
\hline Weak & & & & & no & positive & -1 \\
\hline Very Weak & & & & & & no & -2 \\
\hline
\end{tabular}

Figure 4. M-MACBETH consistent matrix of judgments for "Products and services".

The descriptor of the qualitative performance of each mutual fund $f, f=1,2, \cdots, 46$ in each criterion $i$ belonging to the environment dimension, $j=2$, is obtained as follows:

$$
M F_{i}^{f}=\sum_{s=1}^{p} \alpha_{s}^{f} v\left(F_{i s}^{f}\right), f=1,2, \cdots, 46
$$

where $p$ is the number of firms invested in by mutual fund $f$, and $0 \leq \alpha_{s}^{f} \leq 1$ is the weighting of firm $s$ in mutual fund $f$, with $\sum_{s=1}^{p} \alpha_{s}^{f}=1$ (this information was provided by Morningstar). Tables 8-11 display the value 


\begin{tabular}{|c|c|c|c|c|c|c||r|}
\hline & Strongly Good & Very Good & Good & Neutral & Weak & Very Weak & $\begin{array}{c}\text { Current } \\
\text { scale }\end{array}$ \\
\hline Strongly Good & no & strong & strong & strong & v. strong & extreme & 4 \\
\hline Very Good & & no & moderate & strong & strong & strong & 2 \\
\hline Good & & & no & moderate & strong & strong & 1 \\
\hline Neutral & & & & no & moderate & strong & 0 \\
\hline Weak & & & & & no & moderate & -1 \\
\hline Very Weak & & & & & & no & -2 \\
\hline
\end{tabular}

Figure 5. M-MACBETH consistent matrix of judgments for “Operations Management.

\begin{tabular}{|c|c|c|c|c||r|}
\hline & Good & Neutral & Weak & Very Weak & $\begin{array}{c}\text { Current } \\
\text { scale }\end{array}$ \\
\hline Good & no & moderate & strong & positive & 1 \\
\hline Neutral & & no & moderate & positive & 0 \\
\hline Weak & & & no & positive & -1 \\
\hline Very Weak & & & & no & -2 \\
\hline
\end{tabular}

Figure 6. M-MACBETH consistent matrix of judgments for "Others".

Table 8. Descriptor of mutual funds' qualitative performance and effect value scale for criterion "Climate Change” within the "Environment" dimension.

\begin{tabular}{ccc}
\hline Levels of performance & $M F_{i}^{f}$ & $v\left(M F_{i}^{f}\right)$ \\
\hline Good & 1 & 1 \\
Neutral & 0 & 0 \\
Weak & -0.5 & -1 \\
Very Week & -1 & -2 \\
\hline
\end{tabular}

Table 9. Descriptor of mutual funds' qualitative performance and effect value scale for criterion "Products and Services" within the "Environment" dimension.

\begin{tabular}{ccc}
\hline Levels of performance & $M F_{i}^{f}$ & $v\left(M F_{i}^{f}\right)$ \\
\hline Strongly Good & 10 & 3 \\
Very Good & 8 & 1 \\
Good & 6 & 0 \\
Neutral & 4 & -1 \\
Weak & 2 & -2 \\
Very Week & 0 & \\
\hline
\end{tabular}

scales (obtained by cross-multiplication), for mutual funds' qualitative performance:

Financial performance of each mutual fund is measured using Morningstar Rating TM for funds. This rating, often called the "star rating", debuted in 1985 and was quickly embraced by investors and advisors. The rating is a quantitative assessment of a fund's past performance-both return and risk-as measured from one to five stars. It uses focused comparison groups to better measure the fund manager skill. Thus, the rating allows investors to distinguish among funds that use similar investment strategies. The method rates funds based on an enhanced Morningstar Risk-Adjusted Return measure, which also accounts for the effects of all sales charges, loads, or redemption fees. The original methodology defined risk as the underperformance relative to the 90-day Treasury Bills. With the enhanced methodology, risk is measured as the amount of variation in the fund's per- 
Table 10. Descriptor of mutual funds' qualitative performance and effect value scale for criterion “Operations Management” within the "Environment" dimension.

\begin{tabular}{ccc}
\hline Levels of performance & $M F_{i}^{f}$ & $v\left(M F_{i}^{f}\right)$ \\
\hline Strongly Good & 14 & 4 \\
Very Good & 9 & 2 \\
Good & 6 & 0 \\
Neutral & 3 & -1 \\
Weak & 1 & -2 \\
Very Week & -2 & -2 \\
\hline
\end{tabular}

Table 11. Descriptor of mutual funds' qualitative performance and effect value scale for criterion “Others” within the "Environment" dimension.

\begin{tabular}{ccc}
\hline Levels of performance & $M F_{i}^{f}$ & $v\left(M F_{i}^{f}\right)$ \\
\hline Good & 0 & 1 \\
Neutral & -0.66 & -1 \\
Weak & -1.33 & -2 \\
Very Week & -2 & -2 \\
\hline
\end{tabular}

formance, with more emphasis on downward variation. The Morningstar Rating TM is based on "expected utility theory". The rating accounts for all variations in a fund's monthly performance, with more emphasis on downward variations. It rewards consistent performance and reduces the possibility of strong short-term performance masking the inherent risk of a fund (see www.morningstar.com and Table 12 and Figure 7).

Table A1, Table A2 and Table A3 in the appendix display values assigned to the performance of each mutual fund whit respect to each criterion.

\section{Criteria Weighting and Additive Aggregation}

We defined a fictitious mutual fund called "neutral" mutual fund (a mutual fund which is neutral in every criterion). The investor was first asked to answer the following questions: How much would a swing from neutral to each of the good performance levels for the 10 criteria, increase its overall attractiveness? With these answers the investor filled the last column in the judgments matrix. Then the investor was asked to judge the difference in attractiveness between from the most attractive swing to the second most attractive swing: How much more attractive is a swing from neutral to good in climate change than a swing from neutral to good in products and services? and so on, until completing the M-MACBETH judgments matrix Figure 8 (see Bana e Costa, et al. 2003 for more technical details).

The histogram in Figure 9 shows the derived M-MACBETH weights (in percentages). The total value score $V^{f}$ for mutual fund $\mathrm{f}$ is obtained as:

$$
V^{f}=\sum_{i_{j}=1}^{N_{j}} V_{i j}^{f} \times w_{i j}, f=1, \cdots, 46, j=1,2,3
$$

where: $w_{i j}$ is the weight given to criterion $i$ in dimension $\mathrm{j}$ and $V_{i j}^{f}$ the value score for mutual fund $\mathrm{f}$ with respect to criterion $i$ within dimension j. $\sum_{i_{j}=1}^{N_{j}} w_{i j}=1$ and $w_{i j} \geq 0, \forall i, j$, and $V_{i j}^{f}=1$ when the performance of mutual fund $\mathrm{f}$ in the evaluation criterion $i_{j}$ equals the criterion target "good" and $V_{i j}^{f}=0$ when mutual fund $f$ has the neutral performance related to that criterion. Figure 10 displays the overall and partial scores (all values 
Table 12. Descriptor of mutual funds’ qualitative performance and effect value scale for criterion “Adjusted Return” within the "Environment" dimension.

\begin{tabular}{|c|c|c|c|c|c|c|c|c|c|c|c|}
\hline \multicolumn{12}{|c|}{ Levels of performance } \\
\hline \multicolumn{12}{|c|}{0 Morningstar stars } \\
\hline \multicolumn{12}{|c|}{1 Morningstar stars } \\
\hline \multicolumn{12}{|c|}{2 Morningstar stars } \\
\hline \multicolumn{12}{|c|}{3 Morningstar stars } \\
\hline \multicolumn{12}{|c|}{4 Morningstar stars } \\
\hline \multicolumn{12}{|c|}{5 Morningstar stars } \\
\hline & & & 5 starts & 4 starts & 3 starts & 2 starts & 1 starts & 0 starts & $\begin{array}{l}\text { Current } \\
\text { scale }\end{array}$ & & \\
\hline & & 5 starts & no & moderate & strong & strong & v. strong & extreme & 2.0 & & \\
\hline & & 4 starts & & no & moderate & strong & strong & v. strong & 1.5 & & \\
\hline & & 3 starts & & & no & moderate & strong & strong & 1.0 & & \\
\hline & & 2 starts & & & & no & moderate & strong & 0.5 & & \\
\hline & & 1 starts & & & & & no & moderate & 0.0 & & \\
\hline & & 0 starts & & & & & & no & -0.5 & & \\
\hline \multicolumn{12}{|c|}{ Figure 7. M-MACBETH consistent matrix of judgments for “Others”. } \\
\hline & [Adiretur] & [0perat Manag] ] & [Product-Serv] & [ Climate Change ] & [ screening ] & [ advocacy] & [ research] & [ ext control] & [ manag compet] & [Other] & [all lower ] \\
\hline [Adiretur] & no & strong & strong & strong & strong & strong & v. strong & v. strong & v. strong & v. strong & exteme \\
\hline [Operat Manag] & & no & positive & positive & positive & positive & positive & positive & positive & v. strong & v. strong \\
\hline [Product-Serv] & & & no & positive & positive & positive & positive & positive & positive & positive & v. strong \\
\hline [Climate Change] & & & & no & positive & positive & positive & positive & positive & positive & v. strong \\
\hline [ screening] & & & & & no & positive & positive & positive & positive & positive & strong \\
\hline [ advocacy] & & & & & & no & positive & positive & positive & positive & strong \\
\hline [ research] & & & & & & & no & positive & positive & positive & strong \\
\hline [ext control] ] & & & & & & & & no & positive & positive & strong \\
\hline [ manag compet] & & & & & & & & & no & positive & strong \\
\hline [Other] & & & & & & & & & & no & strong \\
\hline [all lower ] & & & & & & & & & & & no \\
\hline
\end{tabular}

Figure 8. Consistent matrix of judgments obtained using M-MACBETH.

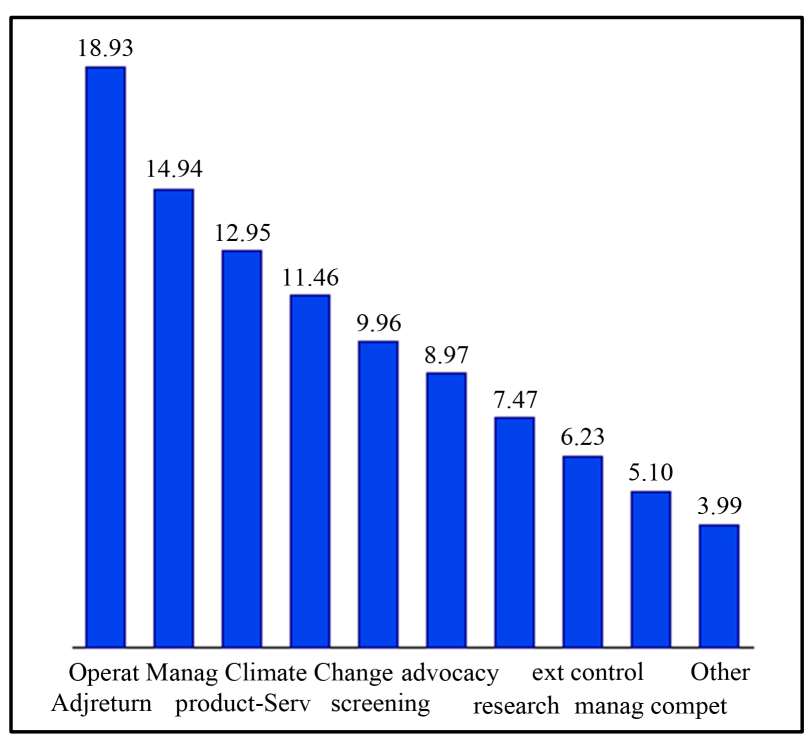

Figure 9. Histogram containing weigths obtained using $\mathrm{M}$ MACBETH. 


\begin{tabular}{|c|c|c|c|c|c|c|c|c|c|c|c|}
\hline Options & Overall & screening & advocacy & research & ext control & manag compet & Climate Change & Product_Serv & Operat Manag & Other & Adireturn \\
\hline F1 & 26.54 & 300.00 & 100.00 & 100.00 & -100.00 & -100.00 & 0.00 & -200.00 & -100.00 & 100.00 & 150.00 \\
\hline F2 & 26.54 & 300.00 & 100.00 & 100.00 & -100.00 & -100.00 & 0.00 & -200.00 & -100.00 & 100.00 & 150.00 \\
\hline F3 & 26.54 & 300.00 & 100.00 & 100.00 & -100.00 & -100.00 & 0.00 & -200.00 & -100.00 & 100.00 & 150.00 \\
\hline F4 & 36.00 & 300.00 & 100.00 & 100.00 & -100.00 & -100.00 & 0.00 & -200.00 & -100.00 & 100.00 & 200.00 \\
\hline F5 & -1.86 & 300.00 & 100.00 & 100.00 & -100.00 & -100.00 & 0.00 & -200.00 & -100.00 & 100.00 & 0.00 \\
\hline F6 & 145.06 & 300.00 & 100.00 & 100.00 & -100.00 & -100.00 & -100.00 & 300.00 & 400.00 & 100.00 & 100.00 \\
\hline F7 & 135.60 & 300.00 & 100.00 & 100.00 & -100.00 & -100.00 & -100.00 & 300.00 & 400.00 & 100.00 & 50.00 \\
\hline F8 & 145.06 & 300.00 & 100.00 & 100.00 & -100.00 & -100.00 & -100.00 & 300.00 & 400.00 & 100.00 & 100.00 \\
\hline F9 & 145.06 & 300.00 & 100.00 & 100.00 & -100.00 & -100.00 & -100.00 & 300.00 & 400.00 & 100.00 & 100.00 \\
\hline F10 & 7.61 & 300.00 & 100.00 & 100.00 & -100.00 & -100.00 & 0.00 & -200.00 & -100.00 & 100.00 & 50.00 \\
\hline F11 & -11.33 & 300.00 & 100.00 & 100.00 & -100.00 & -100.00 & 0.00 & -200.00 & -100.00 & 100.00 & -50.00 \\
\hline F12 & 7.61 & 300.00 & 100.00 & 100.00 & -100.00 & -100.00 & 0.00 & -200.00 & -100.00 & 100.00 & 50.00 \\
\hline F13 & 17.07 & 300.00 & 100.00 & 100.00 & -100.00 & -100.00 & 0.00 & -200.00 & -100.00 & 100.00 & 100.00 \\
\hline F14 & 7.61 & 300.00 & 100.00 & 100.00 & -100.00 & -100.00 & 0.00 & -200.00 & -100.00 & 100.00 & 50.00 \\
\hline F15 & 17.07 & 300.00 & 100.00 & 100.00 & -100.00 & -100.00 & 0.00 & -200.00 & -100.00 & 100.00 & 100.00 \\
\hline F16 & 17.07 & 300.00 & 100.00 & 100.00 & -100.00 & -100.00 & 0.00 & -200.00 & -100.00 & 100.00 & 100.00 \\
\hline F17 & 22.55 & 300.00 & 100.00 & 300.00 & -100.00 & -100.00 & 0.00 & -200.00 & -100.00 & 100.00 & 50.00 \\
\hline F18 & 25.55 & 300.00 & 300.00 & 100.00 & -100.00 & -100.00 & 0.00 & -200.00 & -100.00 & 100.00 & 50.00 \\
\hline F19 & -11.33 & 300.00 & 100.00 & 100.00 & -100.00 & -100.00 & 0.00 & -200.00 & -100.00 & 100.00 & -50.00 \\
\hline F20 & 26.54 & 300.00 & 100.00 & 100.00 & -100.00 & -100.00 & 0.00 & -200.00 & -100.00 & 100.00 & 150.00 \\
\hline F21 & 26.54 & 300.00 & 100.00 & 100.00 & -100.00 & -100.00 & 0.00 & -200.00 & -100.00 & 100.00 & 150.00 \\
\hline F22 & 41.48 & 300.00 & 100.00 & 300.00 & -100.00 & -100.00 & 0.00 & -200.00 & -100.00 & 100.00 & 150.00 \\
\hline F23 & 22.55 & 300.00 & 100.00 & 300.00 & -100.00 & -100.00 & 0.00 & -200.00 & -100.00 & 100.00 & 50.00 \\
\hline F24 & 35.01 & 300.00 & 300.00 & 100.00 & -100.00 & -100.00 & 0.00 & -200.00 & -100.00 & 100.00 & 100.00 \\
\hline F25 & 50.47 & 300.00 & 300.00 & 100.00 & 300.00 & -100.00 & 0.00 & -200.00 & -100.00 & 100.00 & 50.00 \\
\hline F26 & -55.65 & -100.00 & -100.00 & -100.00 & -100.00 & -100.00 & 0.00 & -200.00 & -100.00 & 100.00 & 100.00 \\
\hline F27 & -36.72 & -100.00 & -100.00 & -100.00 & -100.00 & -100.00 & 0.00 & -200.00 & -100.00 & 100.00 & 200.00 \\
\hline F28 & -55.65 & -100.00 & -100.00 & -100.00 & -100.00 & -100.00 & 0.00 & -200.00 & -100.00 & 100.00 & 100.00 \\
\hline F29 & -55.65 & -100.00 & -100.00 & -100.00 & -100.00 & -100.00 & 0.00 & -200.00 & -100.00 & 100.00 & 100.00 \\
\hline F30 & -78.06 & -100.00 & -100.00 & -100.00 & -100.00 & -100.00 & 100.00 & -200.00 & -200.00 & 100.00 & 0.00 \\
\hline F31 & -55.65 & -100.00 & -100.00 & -100.00 & -100.00 & -100.00 & 0.00 & -200.00 & -100.00 & 100.00 & 100.00 \\
\hline F32 & -55.65 & -100.00 & -100.00 & -100.00 & -100.00 & -100.00 & 0.00 & -200.00 & -100.00 & 100.00 & 100.00 \\
\hline F33 & -65.12 & -100.00 & -100.00 & -100.00 & -100.00 & -100.00 & 0.00 & -200.00 & -100.00 & 100.00 & 50.00 \\
\hline F34 & -65.12 & -100.00 & -100.00 & -100.00 & -100.00 & -100.00 & 0.00 & -200.00 & -100.00 & 100.00 & 50.00 \\
\hline F35 & -65.12 & -100.00 & -100.00 & -100.00 & -100.00 & -100.00 & 0.00 & -200.00 & -100.00 & 100.00 & 50.00 \\
\hline F36 & -46.19 & -100.00 & -100.00 & -100.00 & -100.00 & -100.00 & 0.00 & -200.00 & -100.00 & 100.00 & 150.00 \\
\hline F37 & -65.12 & -100.00 & -100.00 & -100.00 & -100.00 & -100.00 & 0.00 & -200.00 & -100.00 & 100.00 & 50.00 \\
\hline F38 & -46.19 & -100.00 & -100.00 & -100.00 & -100.00 & -100.00 & 0.00 & -200.00 & -100.00 & 100.00 & 150.00 \\
\hline F39 & -55.65 & -100.00 & -100.00 & -100.00 & -100.00 & -100.00 & 0.00 & -200.00 & -100.00 & 100.00 & 100.00 \\
\hline F40 & -65.12 & -100.00 & -100.00 & -100.00 & -100.00 & -100.00 & 0.00 & -200.00 & -100.00 & 100.00 & 50.00 \\
\hline F41 & -36.72 & -100.00 & -100.00 & -100.00 & -100.00 & -100.00 & 0.00 & -200.00 & -100.00 & 100.00 & 200.00 \\
\hline F42 & -36.72 & -100.00 & -100.00 & -100.00 & -100.00 & -100.00 & 0.00 & -200.00 & -100.00 & 100.00 & 200.00 \\
\hline F43 & -65.12 & -100.00 & -100.00 & -100.00 & -100.00 & -100.00 & 0.00 & -200.00 & -100.00 & 100.00 & 50.00 \\
\hline F44 & -55.65 & -100.00 & -100.00 & -100.00 & -100.00 & -100.00 & 0.00 & -200.00 & -100.00 & 100.00 & 100.00 \\
\hline F45 & -84.05 & -100.00 & -100.00 & -100.00 & -100.00 & -100.00 & 0.00 & -200.00 & -100.00 & 100.00 & -50.00 \\
\hline F46 & -46.19 & -100.00 & -100.00 & -100.00 & -100.00 & -100.00 & 0.00 & -200.00 & -100.00 & 100.00 & 150.00 \\
\hline [ all upper ] & 100.00 & 100.00 & 100.00 & 100.00 & 100.00 & 100.00 & 100.00 & 100.00 & 100.00 & 100.00 & 100.00 \\
\hline [ all lower ] & 0.00 & 0.00 & 0.00 & 0.00 & 0.00 & 0.00 & 0.00 & 0.00 & 0.00 & 0.00 & 0.00 \\
\hline \multicolumn{2}{|c|}{ Weights } & 0.0996 & 0.0897 & 0.0747 & 0.0623 & 0.0510 & 0.1146 & 0.1295 & 0.1494 & 0.0399 & 0.1893 \\
\hline
\end{tabular}

Figure 10. M-MACBETH table with partial and total scores.

multiplied by 100) for each mutual fund based on the particular preferences of the investor. Two fictitious mutual funds have been included as references for the rating. A fund called "All upper" which reaches the "good” target for every criterion and a fund called "All lower” which is neutral with respect to all criteria.

For each mutual fund we obtain a set of numerical scores referred to the different criteria and an overall score.

As we can observe and based on the judgments of the investor, all "conventional” mutual funds obtain scores that rank them as worst than the neutral reference fund. Only four mutual funds overcome the target fictitious mutual fund. The rest of the mutual funds are better than the "neutral” mutual fund but worst than the "good" fund.

\section{Conclusion}

Investors have a limited capacity for handling large amounts of information and a rating of a fund taking into account both, financial and non-financial aspects can provide a useful tool for investment decision making. In this paper, we have proposed an evaluation model for mutual funds based on their socially responsible and financial performance which allows individual investors to make investment decisions taking into account socially responsible information about the mutual funds. To this aim, we have used a Multicriteria Decision Making Technique, MACBETH, which allows measurement of the Attractiveness of each mutual fund with respect to several qualitative criteria using a Categorical based Evaluation Technique. The application of this approach 
aims to assist a socially responsible individual investor in his/her investment decision process, providing him/her with a ranking for socially responsible mutual funds based on his/her particular preferences.

\section{Acknowledgements}

We would like to thank the "Universidad Complutense de Madrid" and the "Universidad de Oviedo" for their financial support (NILS mobility project (Abel-Call). This work has been financially supported by the Spanish Ministry of Science and Innovation (project ECO2011-28927).

\section{References}

[1] Barnett, M.L. and Salomon, R.M. (2006) Beyond Dichotomy: The Curvilinear Relationship between Social Responsibility and Financial Performance. Strategic Management Journal, 27, 1101-1122. http://dx.doi.org/10.1002/smj.557

[2] Renneboog, L., Horst, J.T. and Zhang, C.D. (2008) Socially Responsible Investments: Institutional Aspects, Performance, and Investor Behavior. Journal of Banking and Finance, 32, 1723-1742. http://dx.doi.org/10.1016/j.jbankfin.2007.12.039

[3] Lee, D.D., Humphrey, J.E., Benson, K.L. and Ahn, J.Y.K. (2010) Socially Responsible Investment Fund Performance: the Impact of Screening Intensity. Accounting and Finance, 50, 351-370. http://dx.doi.org/10.1111/j.1467-629X.2009.00336.x

[4] Jegourel, Y. and Maveyraud, S.A. (2010) A Reassessment of European SRI Funds Underperformance: Does the Intensity of Extra-Financial Negative Screening Matter? Economics Bulletin, 30, 913-923.

[5] Scholtens, B. (2007) Financial and Social Performance of Socially Responsible Investments in the Netherlands. Corporate Governance: An International Review, 15, 1090-1105. http://dx.doi.org/10.1111/j.1467-8683.2007.00633.x

[6] Pérez-Gladish, B. and M’Zali, B. (2010) An AHP-Based Approach to Mutual Funds Social Performance Measurement. International Journal of Multicriteria Decision Making (IJMCDM), 1, 103-127. http://dx.doi.org/10.1504/IJMCDM.2010.033689

[7] Bana e Costa, C.A. and Vansnick, J.-C. (1999) The MACBETH Approach: Basic Ideas, Software, and an Application. In: Meskens, N. and Roubens, M., Eds., Advances in Decision Analysis (Book Series: Mathematical Modelling: Theory and Applications), Vol. 4, Kluwer Academic Publishers, Dordrecht, 131-157.

[8] Bana e Costa, C.A., De Corte, J.M. and Vansnick, J.C. (2003) MACBETH. Working Paper LSEOR 03.56, London School of Economics, London.

[9] Bana e Costa, C.A., Vansnick, J.C. and De Corte, J.M. (2011) MACBETH (Measuring Attractiveness by a Categorical Based Evaluation Technique). In: Cochran, J.J., Eds., Wiley Encyclopedia in Operational Research and Management Science, Wiley, New York, 2945-2950. http://dx.doi.org/10.1002/9780470400531.eorms0970

[10] Bana e Costa, C.A., Barroso, L.A. and Soares, J.O. (2002) Qualitative Modelling of Credit Scoring: A Case Study in Banking. Journal of European Research Studies, 5, 37-51.

[11] Bana e Costa, C.A. and Oliveira, M.D. (2012) A Multicriteria Decision Analysis Model for Faculty Evaluation. OMEGA: The International Journal of Management Science 40, 424-436. www.sciencedirect.com.

[12] Koellner, T., Weber, O., Fenchel, M. and Scholz, R. (2005) Principles of Sustainability Rating of Investment Funds. Business Strategy and the Environment, 14, 54-70. http://dx.doi.org/10.1002/bse.423

[13] KLD (2007) KLD Research. Environmental, Social and Governance Ratings Criteria. www.kld.com 


\section{Appendix}

Table A1. Performance of mutual funds in each criterion within the “Quality of SRI Management” dimension.

\begin{tabular}{|c|c|c|c|c|c|c|c|c|c|c|}
\hline \multicolumn{6}{|c|}{$Q M_{i}{ }^{\prime}=\sum_{k=1}^{K_{i}} S_{k}^{i}$} & \multicolumn{5}{|c|}{$v\left(Q M_{i}^{f}\right)$} \\
\hline funds & $\begin{array}{l}\text { Screening } \\
\text { Approach }\end{array}$ & $\begin{array}{c}\text { Advocacy } \\
\text { \& Public } \\
\text { Policy }\end{array}$ & $\begin{array}{c}\text { SRI } \\
\text { Research } \\
\text { Process }\end{array}$ & $\begin{array}{c}\text { SRI } \\
\text { External } \\
\text { Control }\end{array}$ & $\begin{array}{c}\text { Managers } \\
\text { SRI } \\
\text { competence }\end{array}$ & $\begin{array}{l}\text { Screening } \\
\text { Approach }\end{array}$ & $\begin{array}{c}\text { Advocacy } \\
\text { \& Public } \\
\text { Policy }\end{array}$ & $\begin{array}{c}\text { SRI } \\
\text { Research } \\
\text { Process }\end{array}$ & $\begin{array}{c}\text { SRI } \\
\text { External } \\
\text { Control }\end{array}$ & $\begin{array}{c}\text { Managers } \\
\text { SRI } \\
\text { competence }\end{array}$ \\
\hline F1 & 2 & 1 & 1 & 0 & 0 & Str.Good & VerGood & VerGood & Weak & Weak \\
\hline F2 & 2 & 1 & 1 & 0 & 0 & Str.Good & VerGood & VerGood & Weak & Weak \\
\hline F3 & 2 & 1 & 1 & 0 & 0 & Str.Good & VerGood & VerGood & Weak & Weak \\
\hline F4 & 2 & 1 & 1 & 0 & 0 & Str.Good & VerGood & VerGood & Weak & Weak \\
\hline F5 & 2 & 1 & 1 & 0 & 0 & Str.Good & VerGood & VerGood & Weak & Weak \\
\hline F6 & 2 & 1 & 1 & 0 & 0 & Str.Good & VerGood & VerGood & Weak & Weak \\
\hline F7 & 2 & 1 & 1 & 0 & 0 & Str.Good & VerGood & VerGood & Weak & Weak \\
\hline F8 & 2 & 1 & 1 & 0 & 0 & Str.Good & VerGood & VerGood & Weak & Weak \\
\hline F9 & 2 & 1 & 1 & 0 & 0 & Str.Good & VerGood & VerGood & Weak & Weak \\
\hline F10 & 2 & 1 & 1 & 0 & 0 & Str.Good & VerGood & VerGood & Weak & Weak \\
\hline F11 & 2 & 1 & 1 & 0 & 0 & Str.Good & VerGood & VerGood & Weak & Weak \\
\hline F12 & 2 & 1 & 1 & 0 & 0 & Str.Good & VerGood & VerGood & Weak & Weak \\
\hline F13 & 2 & 1 & 1 & 0 & 0 & Str.Good & VerGood & VerGood & Weak & Weak \\
\hline F14 & 2 & 1 & 1 & 0 & 0 & Str.Good & VerGood & VerGood & Weak & Weak \\
\hline F15 & 2 & 1 & 1 & 0 & 0 & Str.Good & VerGood & VerGood & Weak & Weak \\
\hline F16 & 2 & 1 & 1 & 0 & 0 & Str.Good & VerGood & VerGood & Weak & Weak \\
\hline F17 & 2 & 1 & 3 & 0 & 0 & Str.Good & VerGood & Str.Good & Weak & Weak \\
\hline F18 & 2 & 2 & 1 & 0 & 0 & Str.Good & Str.Good & VerGood & Weak & Weak \\
\hline F19 & 2 & 1 & 2 & 0 & 0 & Str.Good & VerGood & VerGood & Weak & Weak \\
\hline F20 & 2 & 1 & 2 & 0 & 0 & Str.Good & VerGood & VerGood & Weak & Weak \\
\hline F21 & 2 & 1 & 2 & 0 & 0 & Str.Good & VerGood & VerGood & Weak & Weak \\
\hline F22 & 4 & 1 & 3 & 0 & 0 & Str.Good & VerGood & Str.Good & Weak & Weak \\
\hline F23 & 4 & 1 & 3 & 0 & 0 & Str.Good & VerGood & Str.Good & Weak & Weak \\
\hline F24 & 2 & 2 & 1 & 0 & 0 & Str.Good & Str.Good & VerGood & Weak & Weak \\
\hline F25 & 2 & 2 & 1 & 1 & 0 & Str.Good & Str.Good & VerGood & Str.Good & Weak \\
\hline F26 & 0 & 0 & 0 & 0 & 0 & Weak & Weak & Weak & Weak & Weak \\
\hline F27 & 0 & 0 & 0 & 0 & 0 & Weak & Weak & Weak & Weak & Weak \\
\hline F28 & 0 & 0 & 0 & 0 & 0 & Weak & Weak & Weak & Weak & Weak \\
\hline F29 & 0 & 0 & 0 & 0 & 0 & Weak & Weak & Weak & Weak & Weak \\
\hline F30 & 0 & 0 & 0 & 0 & 0 & Weak & Weak & Weak & Weak & Weak \\
\hline
\end{tabular}




\begin{tabular}{|c|c|c|c|c|c|c|c|c|c|c|}
\hline \multicolumn{11}{|c|}{ Continued } \\
\hline F31 & 0 & 0 & 0 & 0 & 0 & Weak & Weak & Weak & Weak & Weak \\
\hline F32 & 0 & 0 & 0 & 0 & 0 & Weak & Weak & Weak & Weak & Weak \\
\hline F33 & 0 & 0 & 0 & 0 & 0 & Weak & Weak & Weak & Weak & Weak \\
\hline F34 & 0 & 0 & 0 & 0 & 0 & Weak & Weak & Weak & Weak & Weak \\
\hline F35 & 0 & 0 & 0 & 0 & 0 & Weak & Weak & Weak & Weak & Weak \\
\hline F36 & 0 & 0 & 0 & 0 & 0 & Weak & Weak & Weak & Weak & Weak \\
\hline F37 & 0 & 0 & 0 & 0 & 0 & Weak & Weak & Weak & Weak & Weak \\
\hline F38 & 0 & 0 & 0 & 0 & 0 & Weak & Weak & Weak & Weak & Weak \\
\hline F39 & 0 & 0 & 0 & 0 & 0 & Weak & Weak & Weak & Weak & Weak \\
\hline F40 & 0 & 0 & 0 & 0 & 0 & Weak & Weak & Weak & Weak & Weak \\
\hline F41 & 0 & 0 & 0 & 0 & 0 & Weak & Weak & Weak & Weak & Weak \\
\hline F42 & 0 & 0 & 0 & 0 & 0 & Weak & Weak & Weak & Weak & Weak \\
\hline F43 & 0 & 0 & 0 & 0 & 0 & Weak & Weak & Weak & Weak & Weak \\
\hline F44 & 0 & 0 & 0 & 0 & 0 & Weak & Weak & Weak & Weak & Weak \\
\hline F45 & 0 & 0 & 0 & 0 & 0 & Weak & Weak & Weak & Weak & Weak \\
\hline F46 & 0 & 0 & 0 & 0 & 0 & Weak & Weak & Weak & Weak & Weak \\
\hline Total & 4 & 2 & 3 & 1 & 1 & & & & & \\
\hline
\end{tabular}

Own source based on information provided by mutual fund websites and SIF.

Table A2. Performance of mutual funds in each criterion within the "Environment" dimension.

\begin{tabular}{|c|c|c|c|c|c|c|c|c|}
\hline \multirow{2}{*}{ FUNDS } & \multicolumn{4}{|c|}{$M F_{i}^{f}$} & \multicolumn{4}{|c|}{$v\left(M F_{i}^{f}\right)$} \\
\hline & $\begin{array}{l}\text { Climate } \\
\text { Change }\end{array}$ & $\begin{array}{l}\text { Products \& } \\
\text { Services }\end{array}$ & $\begin{array}{c}\text { Operations } \\
\text { Management }\end{array}$ & Other & $\begin{array}{l}\text { Climate } \\
\text { Change }\end{array}$ & $\begin{array}{l}\text { Products \& } \\
\text { Services }\end{array}$ & $\begin{array}{c}\text { Operations } \\
\text { Management }\end{array}$ & Other \\
\hline F1 & 0 & 0 & 1 & 0.02 & Neutral & VerWeak & Weak & VerGood \\
\hline F2 & 0 & 0 & 1 & 0.02 & Neutral & VerWeak & Weak & VerGood \\
\hline F3 & 0 & 0 & 1 & 0.02 & Neutral & VerWeak & Weak & VerGood \\
\hline F4 & 0 & 0 & 1 & 0.02 & Neutral & VerWeak & Weak & VerGood \\
\hline F5 & 0 & 0 & 1 & 0.02 & Neutral & VerWeak & Weak & VerGood \\
\hline F6 & -1 & 10 & 14 & -2.33 & Weak & Str.Good & Str.Good & VerWeak \\
\hline F7 & -1 & 10 & 14 & -2.33 & Weak & Str.Good & Str.Good & VerWeak \\
\hline F8 & -1 & 10 & 14 & -2.33 & Weak & Str.Good & Str.Good & VerWeak \\
\hline F9 & -1 & 10 & 14 & -2.33 & Weak & Str.Good & Str.Good & VerWeak \\
\hline F10 & 0 & 0 & 0 & -0.08 & Neutral & VerWeak & Weak & VerGood \\
\hline F11 & 0 & 0 & 0 & -0.08 & Neutral & VerWeak & Weak & VerGood \\
\hline F12 & 0 & 0 & 0 & -0.08 & Neutral & VerWeak & Weak & VerGood \\
\hline
\end{tabular}




\section{Continued}

\begin{tabular}{|c|c|c|c|c|c|c|c|c|}
\hline F13 & 0 & 0 & 1 & -0.05 & Neutral & VerWeak & Weak & VerGood \\
\hline F14 & 0 & 0 & 1 & -0.05 & Neutral & VerWeak & Weak & VerGood \\
\hline F15 & 0 & 0 & 1 & -0.05 & Neutral & VerWeak & Weak & VerGood \\
\hline F16 & 0 & 0 & 1 & -0.05 & Neutral & VerWeak & Weak & VerGood \\
\hline F17 & 0 & 0 & 1 & -0.03 & Neutral & VerWeak & Weak & VerGood \\
\hline F18 & 0 & 0 & 1 & -0.09 & Neutral & VerWeak & Weak & VerGood \\
\hline F19 & 0 & 0 & 0 & 0.01 & Neutral & VerWeak & Weak & VerGood \\
\hline F20 & 0 & 0 & 0 & -0.03 & Neutral & VerWeak & Weak & VerGood \\
\hline F21 & 0 & 0 & 0 & -0.03 & Neutral & VerWeak & Weak & VerGood \\
\hline F22 & 0 & 0 & 0 & -0.05 & Neutral & VerWeak & Weak & VerGood \\
\hline F23 & 0 & 0 & 0 & 0.00 & Neutral & VerWeak & Weak & VerGood \\
\hline F24 & 0 & 0 & 0 & -0.08 & Neutral & VerWeak & Weak & VerGood \\
\hline F25 & 0 & 0 & 0 & -0.06 & Neutral & VerWeak & Weak & VerGood \\
\hline F26 & 0 & 0 & 0 & -0.07 & Neutral & VerWeak & Weak & VerGood \\
\hline F27 & 0 & 0 & 0 & -0.16 & Neutral & VerWeak & Weak & VerGood \\
\hline F28 & 0 & 0 & 0 & -0.05 & Neutral & VerWeak & Weak & VerGood \\
\hline F29 & 0 & 0 & 0 & -0.16 & Neutral & VerWeak & Weak & VerGood \\
\hline F30 & 1 & 0 & -2 & 0.00 & Very Good & VerWeak & VerWeak & VerGood \\
\hline F31 & 0 & 0 & 0 & -0.06 & Neutral & VerWeak & Weak & VerGood \\
\hline F32 & 0 & 0 & 1 & 0.02 & Neutral & VerWeak & Weak & VerGood \\
\hline F33 & 0 & 0 & 0 & -0.08 & Neutral & VerWeak & Weak & VerGood \\
\hline F34 & 0 & 0 & 0 & -0.42 & Neutral & VerWeak & Weak & VerGood \\
\hline F35 & 0 & 0 & 0 & -0.29 & Neutral & VerWeak & Weak & VerGood \\
\hline F36 & 0 & 0 & 0 & -0.01 & Neutral & VerWeak & Weak & VerGood \\
\hline F37 & 0 & 0 & 0 & -0.05 & Neutral & VerWeak & Weak & VerGood \\
\hline F38 & 0 & 0 & 0 & 0.00 & Neutral & VerWeak & Weak & VerGood \\
\hline F39 & 0 & 0 & 0 & -0.10 & Neutral & VerWeak & Weak & VerGood \\
\hline F40 & 0 & 0 & 1 & 0.00 & Neutral & VerWeak & Weak & VerGood \\
\hline F41 & 0 & 0 & 0 & -0.02 & Neutral & VerWeak & Weak & VerGood \\
\hline F42 & 0 & 0 & 0 & -0.02 & Neutral & VerWeak & Weak & VerGood \\
\hline F43 & 0 & 0 & 1 & -0.06 & Neutral & VerWeak & Weak & VerGood \\
\hline F44 & 0 & 0 & 0 & -0.04 & Neutral & VerWeak & Weak & VerGood \\
\hline F45 & 0 & 0 & 1 & -0.01 & Neutral & VerWeak & Weak & VerGood \\
\hline F46 & 0 & 0 & 1 & 0.00 & Neutral & VerWeak & Weak & VerGood \\
\hline
\end{tabular}

Own source based on KLD database for 2004. 
Table A3. Performance of mutual funds within the "Financial” dimension.

\begin{tabular}{|c|c|c|}
\hline FUNDS & Adjusted Return (Morningstar stars) & Value (stars) \\
\hline F1 & 4 & 1.5 \\
\hline F2 & 4 & 1.5 \\
\hline F3 & 4 & 1.5 \\
\hline F4 & 5 & 2 \\
\hline F5 & 0 & -0.5 \\
\hline F6 & 3 & 1 \\
\hline F7 & 2 & 0.5 \\
\hline F8 & 3 & 1 \\
\hline F9 & 3 & 1 \\
\hline F10 & 2 & 0.5 \\
\hline F11 & 1 & 0 \\
\hline F12 & 2 & 0.5 \\
\hline F13 & 3 & 1 \\
\hline F14 & 2 & 0.5 \\
\hline F15 & 3 & 1 \\
\hline F16 & 3 & 1 \\
\hline F17 & 2 & 0.5 \\
\hline F18 & 2 & 0.5 \\
\hline F19 & 1 & 0 \\
\hline F20 & 4 & 1.5 \\
\hline F21 & 4 & 1.5 \\
\hline F22 & 4 & 1.5 \\
\hline F23 & 2 & 0.5 \\
\hline F24 & 3 & 1 \\
\hline F25 & 2 & 0.5 \\
\hline F26 & 3 & 1 \\
\hline F27 & 5 & 2 \\
\hline F28 & 3 & 1 \\
\hline F29 & 3 & 1 \\
\hline F30 & 0 & -0.5 \\
\hline F31 & 3 & 1 \\
\hline F32 & 3 & 1 \\
\hline
\end{tabular}




\begin{tabular}{cccc} 
Continued & & 2 & 0.5 \\
\hline F33 & 2 & 0.5 \\
F34 & 2 & 0.5 \\
F35 & 4 & 1.5 \\
F36 & 2 & 0.5 \\
F37 & 4 & 1.5 \\
F38 & 3 & 1 \\
F39 & 2 & 0.5 \\
F40 & 5 & 2 \\
F41 & 5 & 2 \\
F42 & 5 & 0.5 \\
F43 & 2 & 1 \\
F44 & 3 & 0 \\
F45 & 1 & 1.5 \\
F46 & 4 & 2
\end{tabular}

Source: Morningstar data for 2004. 